\title{
Hubungan pola pemberian makan dan sanitasi lingkungan dengan kejadian stunting pada balita di Kelurahan Remu Selatan Kota Sorong
}

\author{
Jenni Lilis. S. Siagian ${ }^{1 *}$, Demianus F Wonatoray ${ }^{2}$, Handayani Thamrin ${ }^{3}$ \\ 1,2,3 Program Studi Kesehatan Masyarakat Sekolah Tingggi IImu Kesehatan Papua
}

\section{INFORMASI ARTIKEL:}

\begin{tabular}{l}
\hline Riwayat Artikel: \\
Tanggal diterima, 26 Juli 2021 \\
Tanggal direvisi, 26 November 2021 \\
Tanggal dipublikasi, 5 Desember 2021 \\
\hline Kata kunci: \\
Stunting; \\
Pola pemberian makan; \\
Sanitasi lingkungan;
\end{tabular}

10.32536/jrki.v5i2.183

Key word :

Stunting;

Pattern of feeding;

Environmental sanitation;

\begin{abstract}
ABSTRAK
Latar belakang: Stunting adalah masalah kurang gizi kronis yang disebabkan oleh asupan gizi yang kurang dalam waktu cukup lama akibat pemberian makanan yang tidak sesuai dengan kebutuhan gizi. Keadaan ini dapat terjadi sejak masa kehamilan. Dampak dari stunting bisa menyebabkan terganggunya perkembangan otak, kecerdasan berkurang, gangguan pertumbuhan fisik dan metabolism dalam tubuh terganggu. Jumlah anak status gizi buruk dan gizi kurang di Provinsi Papua Barat sebanyak 16,18\%, sangat pendek 37,79\% dan pendek $27,36 \%$. Kota Sorong merupakan salah satu daerah dengan angka stunting tertinggi di Indonesia yakni sebanyak 12,3\%. Terdapat 55 balita $(18,46 \%)$ dari 298 balita di Kelurahan Remu Selatan. Tujuan penelitian: Menganalisis hubungan pola pemberian makan dan sanitasi lingkungan dengan kejadian stunting pada anak di Kelurahan Remu Selatan Kota Sorong Metode: Jenis penelitian ini adalah deskriktif analitik dengan rancangan cross sectional. Jumlah sampel sebanyak 55 orang anak usia 6-24 bulan. Data dikumpulkan dengan menggunakan kuesioner, lembar observasi, Lengthboard. Analisa data menggunakan uji Fisher's exact. Hasil: Berdasarkan hasil uji statistik diketahui pola pemberian makan dengan $p$-value $=0,002$, dan sanitasi lingkungan dengan $p$-value $=0,001$ yang artinya pola pemberian makan dan sanitasi lingkungan berhubungan dengan kejadian stunting. Simpulan: Pola pemberian makan dan sanitasi lingkungan berhubungan dengan kejadian stunting pada di Kelurahan Remu Kota Sorong.
\end{abstract}

Background: Stunting is a problem of chronic malnutrition caused by a lack of nutrient intake for a long time due to the provision of food that does not comply with nutritional needs. This condition can occur during pregnancy. The impact of stunting can disrupt brain development, reduce intelligence, impair physical growth, and disturb metabolism in the body. The number of children with poor nutritional status and malnutrition in West Papua Province is $16.18 \%$, very short $37.79 \%$, and short $27.36 \%$. Sorong City is one of the areas with the highest stunting rate in Indonesia, which is $12.3 \%$. There are 55 children (18.46\%) out of 298 toddlers at South Remu Village. Objectives: To analyze the correlation between feeding patterns and environmental sanitation with the incidence of stunting in children at Remu Selatan Village, Sorong City. Methods: This type of research is descriptive-analytic with a cross-sectional design. The number of samples was 55 children aged 6-24 months. Data were collected using a questionnaire, observation sheet, Length board. Data analysis used Fisher's exact test. Results: Based on the results of statistical tests, it was found that the feeding pattern with $p$-value $=0.002$, and environmental sanitation with $p$-value $=0.001$ meant that the feeding pattern and environmental sanitation were correlated with the incidence of stunting. Conclusion: The pattern of feeding and environmental sanitation is correlated with the incidence of stunting at Remu Village, Sorong City. 


\section{Pendahuluan}

Stunting merupakan kondisi keadaan anak balita memiliki panjang atau tinggi badan kurang bila dibandingkan dengan umur (Kemenkes RI 2018). Dikatakan stunting apabila berdasarkan hasil pengukuran, seorang anak memiliki Z-score <3,0 SD sampai dengan -2,0 SD. Stunting akan memengaruhi kesehatan, pertumbuhan dan perkembangan anak termasuk tingkat intelektual, sehingga anak tidak mampu berfikir dan belajar secara optimal dibanding anak yang normal. Kejadian ini telah menjadi masalah besar di seluruh Indonesia, sehingga menjadi perhatian besar di dunia secara global khususnya kesehatan.

Menurut organisasi kesehatan dunia diproyeksikan pada tahun 2025 jumlah anak dibawah usia 5 tahun yang mengalami stunting sebanyak 128 juta yang menyebar di seluruh dunia (WHO, 2014). Pada tahun 2018 Indonesia termasuk dalam 3 negara terbanyak yang memiliki angka anak stunting di Asia Tenggara yaitu ratarata sebesar 36,4\% pada tahun 2015-2017. Jumlah anak stunting di Indonesia tahun 2018 sebanyak 7,8 juta $(35,6 \%)$ dengan jumlah anak sebanyak 23 juta. Jumlah anak stunting di Provinsi Papua Barat sebanyak 19,35\% (Lembaga Penerbit Badan Penelitian dan Pengembangan Kesehatan 2018), sedangkan di Kota Sorong sebanyak 12,3\% dari jumlah anak.

Terjadinya stunting pada anak tidak hanya disebabkan oleh satu faktor saja, melainkan banyak faktor yang saling berhubungan, seperti kurang gizi pada ibu hamil, kurangnya asupan gizi, status sosial ekonomi keluarga, bayi mengalami kesakitan (Kemenkes RI 2018). Menurut Anggraini \& Rusdi (2020), sanitasi lingkungan memengaruhi status kesehatan anak balita. Sanitasi lingkungan yang bersih berdampak pada status gizi baik. Menurut Ernawati (2020), salah satu penyebab stunting pada balita adalah sanitasi kurang. Anak yang tinggal di lingkungan dengan kualitas sarana sanitasi yang tidak memenuhi syarat berisiko 31,875 kali mengalami stunting (Herawati et al. 2020).

Faktor sanitasi lingkungan yang kurang baik di masyarakat atau keluarga seperti kebersihan lingkungan rumah baik di dalam maupun di luar dan tindakan membakar sampah, merupakan faktor penyebab kejadian stunting (Vilcins et al. 2018). Anak dengan sanitasi lingkungan yang buruk memiliki risiko sebesar 4,6 kali terjadi stunting dibanding anak dengan status lingkungan baik (Rahman et al. 2017).

Stunting juga dapat disebabkan oleh pola pemberian makan yang tidak tepat sesuai dengan kebutuhan anak (Lestari et al. 2014). Praktik pemberian makan berhubungan dengan kejadian stunting. Praktik pemberian makan kurang baik memiliki risiko 2,037 mengalami stunting dibanding dengan anak dengan praktik pemberian makan yang baik (Niga \& Purnomo, 2016).

Berdasarkan data yang diperoleh, diketahui di Kelurahan Remu Selatan jumlah anak usia 6-24 bulan sebanyak 298 orang, dan jumlah balita yang mengalami stunting sebanyak 55 orang (Puskesmas Remu, 2019). Tujuan pelaksanaan penelitian adalah mengetahui hubungan pola pemberian makan dan sanitasi lingkungan dengan kejadian stunting pada anak di Kelurahan Remu Selatan Kota Sorong.

\section{Metode penelitian}

Jenis penelitian ini adalah deskriptif analitik dengan variabel bebas adalah pola pemberian makan dan sanitasi lingkungan, variabel dependen adalah kejadian stunting. Jumlah sampel sebanyak 55 orang anak usia 6-24 bulan. Data dikumpulkan dengan menggunakan, kuesioner, memberikan penilaian melalui lembar observasi dan pengukuran tinggi badan. Kuesioner tentang pola pemberian makan terdiri dari 15 pertanyaan positif, hasil uji validitas $r$-hitung $>r$-tabel $(0,444)$ dan nilai Alpha Crocbach $=0,895$, sanitasi lingkungan terdiri dari 10 pertanyaan positif dengan hasil uji validitas $r$-hitung $>$ r-tabel $(0,444)$ dan nilai Alpha Crocbach $=0,687$. Sampel diambil secara total sampling, dan data yang diperoleh dianalisa menggunakan uji Fisher's exact, pada tingkat kepercayaan 0,05.

\footnotetext{
* Korespondensi penulis.

Alamat E-mail: siagianjennililis@gmail.com
} 


\section{Hasil dan Pembahasan}

Data distribusi karakteristik responden disajikan pada Tabel 1.

Tabel 1. Karakteristik responden berdasarkan usia dan jenis kelamin

\begin{tabular}{ccc}
\hline \multicolumn{1}{c}{ Karakteristik } & frekuensi & $\%$ \\
\hline Umur & & \\
\hline $6-11$ & 39 & 70.9 \\
$12-24$ & 16 & 29,1 \\
\hline Jumlah & 55 & 100.0 \\
\hline Jenis kelamin & & \\
\hline Laki-laki & 38 & 69.1 \\
Perempuan & 17 & 30.9 \\
\hline Jumlah & 55 & 100.0 \\
\hline
\end{tabular}

Berdasarkan tabel 1 diketahui 39 orang (70,9\%) usia $6-11$ bulan, dan 38 orang $(69,1 \%)$ berjenis kelamin laki-laki.

Tabel 2. Hubungan pola pemberian makan dan sanitasi lingkungan dengan kejadian stunting

\begin{tabular}{|c|c|c|c|c|c|}
\hline \multirow{3}{*}{$\begin{array}{l}\text { Pola Pemberian } \\
\text { Makan }\end{array}$} & \multicolumn{4}{|c|}{ Kejadian Stunting } & \multirow[t]{3}{*}{$p$-value } \\
\hline & \multicolumn{2}{|c|}{ Stunting } & \multicolumn{2}{|c|}{$\begin{array}{c}\text { Tidak } \\
\text { Stunting }\end{array}$} & \\
\hline & $F$ & $\%$ & $f$ & $\%$ & \\
\hline Kurang & 29 & 52,7 & 4 & 7,3 & \\
\hline Baik & 10 & 18,3 & 12 & 21,8 & 0,002 \\
\hline \multicolumn{6}{|l|}{$\begin{array}{l}\text { Sanitasi } \\
\text { Lingkungan }\end{array}$} \\
\hline Kurang & 28 & 50,9 & 3 & 5,5 & 0,001 \\
\hline Baik & 11 & 20 & 13 & 23,6 & \\
\hline
\end{tabular}

Berdasarkan tabel 2, diketahui pola pemberian makan kurang baik yang mengalami stunting sebanyak 29 balita $(52,7 \%)$ dan pola pemberian makan baik yang mengalami stunting sebanyak 12 balita (21,8\%). Hasil uji statistik diperoleh $p$-value $0,002(p<0,05)$, disimpulkan bahwa pola pemberian makan berhubungan dengan kejadian stunting pada anak usia 6-24 bulan di Kelurahan Remu Selatan Kota Sorong.

Secara teori salah satu penyebab terjadinya stunting adalah pola pemberian makan yang tidak tepat atau tidak baik. Pola pemberian makan merupakan gambaran tindakan seseorang maupun kelompok dalam upaya pemenuhan kebutuhan makan sehari-hari, mencakup pemilihan makanan, kepercayaan yang dianut dan sikap. Menurut Yustianingrum \& Adriani (2017), pola pemberian makan yang baik adalah merupakan tindakan pemberian makan yang disesuaikan dengan usia dan kebutuhan anak agar tidak menjadi penyebab terjadinya masalah kesehatan.
Hasil penelitian ini sejalan dengan penelitian Putra et al. (2020), yang menyatakan bahwa pemberian makan pada balita usia 12-59 bulan adalah $58,5 \%$ baik dan $41,5 \%$ kurang baik. Berdasarkan hasil uji statistik diketahui ada hubungan praktik pemberian makan dengan stunting di Desa Juking Pajang. Didukung oleh penelitian yang dilakukan Danita (2018), pola pemberian makan memiliki pengaruh terhadap kejadian stunting dengan besar risiko 5,1 kali artinya pola pemberian makan yang buruk meningkatkan kejadian stunting 5,1 kali Iwbih besar dibandingkan dengan pola pemberian makan yang baik

Menurut Yudianti \& Saeni (2017) salah satu peluang terjadinya stunting adalah pola pemberian makan yang kurang baik dan sebaiknya pada saat memberikan anak makan dalam suasana yang nyaman, sabar dan penuh perhatian, kasih sayang dan sesuai selera anak sehingga nantinya anak menghabiskan porsi makanan yang disediakan. Anak yang mampu menghabiskan porsi makannya tidak akan mengalami kekurangan gizi apalagi ketika makanan tersebut disajikan sesuai dengan kebutuhannya. Pola pengasuhan anak dalam hal ini pemberian makan yang tepat dapat memberi kontribusi yang besar dalam penentuan status gizi anak (Khofiyah, 2019).

Pola pemberian makan yang harus dilakukan orangtua dan keluarga adalah memberikan anak makan minimal 3 kali sehari yakni pagi, siang dan sore hari namun tidak melebihi batas waktu misalnya makan pagi sebelum pukul sembilan atau batas paling akhir pukul sembilan, demikian juga pada sore hari pukul lima-enam paling lama pukul tujuh malam. Menu makanan pada makan pagi adalah mengandung protein tinggi, sedikit karbohidrat, dan buah, porsi tidak terlalu banyak karena akan membuat anak mengantuk. Untuk makan siang sebagai waktu makan utama porsi bisa lebih banyak tetapi diusahakan menu memenuhi kandungan karbohidrat, protein, sayuran, dan buah-buahan, sedangkan sore menu makan adalah mengandung protein, karbohidrat, sayuran, dan buah-buahan, namun jika anak mengalami lapar pada malam hari berikan asupan protein seperti susu sebab jika diberikan karbohidrat dan lemak dapat mengganggu waktu tidur anak.

Pola pemberian makan yang baik dalam upaya pemenuhan kebutuhan gizi anak salah satunya 
adalah memperhatikan frekuensi makan, karena ini merupakan faktor paling dominan dalam peningkatan status gizi anak (Hasyim \& Sulistianingsih, 2019).

Makanan yang diberikan kepada anak itu harus seimbang, bergizi dan bervariasi sesuai kebutuhan. Dengan pola pemberian makan yang tepat dan benar dapat mengoptimalkan upaya penurunan kejadian stunting untuk mencapai generasi penerus bangsa yang berkualitas.

Namun dalam tindakan pelaksanaan pola makan yang tepat, ibu dan seluruh anggota keluarga membutuhkan bantuan dari petugas kesehatan (Krisnana et al. 2019). Petugas kesehatan dapat berperan sebagai educator dan pengawas.

Berdasarkan hasil penelitian diketahui sanitasi lingkungan yang mengalami stunting sebanyak 28 orang $(50,9 \%)$ dan sanitasi lingkungan baik yang mengalami stunting sebanyak 13 orang $(23,6 \%)$. Berdasarkan hasil uji statistik diperoleh $p$-value $0,001(p<0,05)$ disimpulkan bahwa stunting dapat disebabkan sanitasi lingkungan yang tidak baik pada anak usia 6-24 bulan di Kelurahan Remu Selatan Kota Sorong. Sanitasi lingkungan merupakan suatu upaya manusia dalam mengendalikan semua faktor lingkungan fisik sekitarnya yang dapat menimbulkan atau merugikan perkembangan fisik, daya tahan hidup dan kesehatan manusia itu sendiri. Cakupan sanitasi lingkungan adalah sarana air bersih, tempat pembuangan sampah, sarana pembuangan tinja dan saluran pengelolaan air limbah.

Menurut Wulandari et al. (2019), salah satu penyebab terjadinya stunting adalah kurangnya akses sanitasi, karena buruknya akses terhadap sanitasi air bersih dan fasilitas sanitasi dapat meningkatkan kejadian penyakit infeksi dan keadaan ini membuat proses pertumbuhan dan perkembangan berhenti karena system organ tubuh berfokus pada perlawanan menghadapi infeksi yang dialami. Kejadian ini dapat terjadi karena sanitasi yang buruk dapat menjadi sumber timbulnya penyakit infeksi seperti diare, muntah berak, kecacingan dan alergi. Dampak yang paling terlihat dari kejadian infeksi ini adalah menurunnya berat badan yang drastis, dan apabila terjadi secara berulang dan dalam waktu yang lama dapat menjadi stunting.
Hasil penelitian Aisah et al. (2019) mengatakan bahwa sanitasi lingkungan berhubungan dan merupakan faktor protektif terhadap kejadian stunting pada anak. Rahayu (2019) mengungkapkan bahwa $31,6 \%$ balita memiliki sanitasi lingkungan tidak baik, dan berdasarkan hasil penelitian diketahui kejadian stunting berhubungan dengan sanitasi lingkungan.

Hasil penelitian sejalan dengan penelitian yang dilakukan Anggraini Y \& Rusdi, P.H.N (2020) yang menyatakan ada hubungan sanitasi lingkungan dengan kejadian stunting. Sanitasi lingkungan memiliki kaitan dengan segala sesuatu yang mencakup perilaku semua orang yang berdiam di rumah atau lingkungan tinggal tersebut, misalnya perilaku yang membiasakan bahwa air minum yang dikonsumsi itu adalah merupakan air yang sudah diolah dengan baik. Kebiasaan ini dapat mencegah masuknya bakteri atau kuman ke dalam tubuh yang dapat mengganggu keseimbangan organ tubuh dalam bekerja.

Selain itu pergerakan dan aktivitas anak yang cukup banyak di lingkungan tinggal, proses perawatan anak yang tidak memadai termasuk dalam cakupan sanitasi lingkungan ini. Untuk itu diperlukan perhatian besar terhadap sanitasi lingkungan dan memberi rangsangan psikososial kepada anak sesuai usia sehinga dapat mencapai pertumbuhan dan perkembangan yang optimal. Agar rumah tinggal memenuhi syarat sanitasi lingkungan sesuai dengan ketentuan maka sebaiknya setiap rumah memiliki jamban sendiri, memelihara saluran pengelolaan air limbah, mengolah sampah dengan benar, dan memiliki sumber air bersih.

\section{Simpulan}

Simpulan penelitian ini adalah pola pemberian makan dan sanitasi lingkungan dapat menyebabkan kejadian stunting pada anak di Kelurahan Remu Selatan Kota Sorong. Disarankan kepada Pemerintah Kota Sorong melalui Petugas Kesehatan Puskesmas Remu untuk melakukan pendampingan masyarakat secara maksimal mulai dari awal proses kehamilan sampai dengan minimal 1.000 hari kelahiran. 


\section{Ucapan terima kasih}

Kepada semua pihak yang telah membantu proses pengambilan data yang tidak dapat disebutkan satu persatu.

\section{Daftar Pustaka}

Aisah, Siti, $\mathrm{Rr}$ Dewi Ngaisyah, \& Merita Eka Rahmuniyati. 2019. 'Personal Hygiene Dan Sanitasi Lingkungan Berhubungan Dengan Kejadian Stunting Di Desa Wukirsari Kecamatan Cangkringan'. Prosiding Seminar Nasional Multidisiplin IImu 1(2):49-55.

Anggraini, Yuliza, \& Pagdya Haninda Nusantri Rusdi. 2020. 'Faktor Sanitasi Lingkungan Penyebab Stunting Pada Balita Di Wilayah Kerja Puskesmas Air Bangis Kabupaten Pasaman Barat'. Jurnal Riset Kebidanan Indonesia 4(1):13-16. doi: 10.32536/jrki.v4i1.78.

Danita, Farah. 2018. 'Pengaruh Pola Pemberian Makanan Terhadap Kejadian Stunting Pada Balita'. The Indonesian Journal of Health Science 10(1):15-24.

Ernawati, Aeda. 2020. 'Gambaran Penyebab Balita Stunting Di Desa Lokus Stunting Kabupaten Pati'. Jurnal Litbang: Media Informasi Penelitian, Pengembangan Dan IPTEK 16(2):77-94. doi: 10.33658/jl.v16i2.194.

Hasyim, Dzul Istiqomah, \& Apri Sulistianingsih. 2019. 'Analisis Faktor Yang Berpengaruh Pada Status Gizi (BB/TB) Balita'. Jurnal Riset Kebidanan Indonesia 3(1):20-26. doi: 10.32536/jrki.v3i1.32.

Herawati, Herawati, Andi Anwar, \& Dina Lusiana Setyowati. 2020. 'Hubungan Sarana Sanitasi, Perilaku Penghuni, Dan Kebiasaan Cuci Tangan Pakai Sabun (CTPS) Oleh Ibu Dengan Kejadian Pendek (Stunting) Pada Batita Usia 6-24 Bulan Di Wilayah Kerja Puskesmas Harapan Baru, Samarinda'. Jurnal Kesehatan Lingkungan Indonesia 19(1):7. doi: 10.14710/jkli.19.1.7-15.

Kemenkes RI. 2018. 'Buletin Stunting'. Kementerian Kesehatan RI 301(5):1163-78.
Khofiyah, Nidatul. 2019. 'Hubungan Antara Status Gizi Dan Pola Asuh Gizi Dengan Perkembangan Anak Usia 6-24 Bulan'. Jurnal Riset Kebidanan Indonesia 3(1):37-48. doi: 10.32536/jrki.v3i1.53.

Krisnana, Ilya et al. 2019. 'Feeding Patterns of Children with Stunting Based on WHO (World Health Organization) Determinant Factors of Behaviours Approach'. Indian Journal of Public Health Research and Development 10(8):2756-61. doi: 10.5958/09765506.2019.02288.5.

Lembaga Penerbit Badan Penelitian dan Pengembangan Kesehatan. 2018. Laporan Provinsi Papua Barat Riskesdas 2018. Ma.

Lestari, Wanda, Ani Margawati, \& Zen Rahfiludin. 2014. 'Faktor Risiko Stunting Pada Anak Umur 6-24 Bulan Di Kecamatan Penanggalan Kota Subulussalam Provinsi Aceh'. Jurnal Gizi Indonesia (The Indonesian Journal of Nutrition) 3(1):37-45. doi: 10.14710/jgi.3.1.126-134.

Niga, Desiansi Merlinda, \& Windhu Purnomo. 2016. 'Hubungan Antara Praktik Pemberian Makan, Perawatan Kesehatan, Dan Kebersihan Anak Dengan Kejadian Stunting Pada Anak Usia 1-2 Tahun Di Wilayah Kerja Puskesmas Oebobo Kota Kupang'. Wijaya $3(2): 151-55$.

Puskesmas Remu. 2019. Catatan Rekam Medik. Sorong.

Putra, Yuliana Dewi, H. Fahrurazi, \& Mahmudah. 2020. 'Hubungan Pola Asuh Ibu Dengan Kejadian Stunting Pada Balita Usia 12-59 Bulan Di Desa Juking Pajang Wilayah Kerja Puskesmas Puruk Cahu Kabupaten Murung Raya Provinsi Kalimantan Tengah Tahun 2020'. Hubungan Pola Asuh Ibu Dengan Kejadian Stunting Anak Usia 24-59 Bulan Di Posyandu Asoka II Wilayah Pesisir Kelurahan Barombang Kecamatam Tamalate Kota Makasar 53.

Rahayu. 2019. 'Hubungan Karakteristik Balita, Orang Tua, Higiene Dan Sanitasi Lingkungan Terhadap Stunting Pada Balita'. Binawan Student Journal 1(April):22-27. 
Rahman, Nurdin et al. 2017. 'Determinants of Stunting among Children in Urban Families in Palu, Indonesia'. Pakistan Journal of Nutrition 16(10):750-56.

doi: 10.3923/pjn.2017.750.756.

Vilcins, Dwan, Peter D. Sly, \& Paul Jagals. 2018. 'Environmental Risk Factors Associated with Child Stunting: A Systematic Review of the Literature'. Annals of Global Health 84(4):551-62. doi: 10.29024/aogh.2361.

World Health Organization. 2014. 'Global Nutrition Targets 2025 to Improve Maternal, Infant and Young Child'. World Health Organization 2(6):375-88.

Wulandari, Wulandari Wulandari, Fitri Rahayu, \& . Darmawansyah. 2019. 'Hubungan Sanitasi Lingkungan Dan Riwayat Penyakit Infeksi Dengan Kejadian Stunting Di Wilayah Kerja Puskesmas Kerkap Kabupaten Bengkulu Utara Tahun 2019'. Avicenna: Jurnal IImiah 14(02):6-13.

doi:
Yudianti, Yudianti, \& Rahmat Haji Saeni. 2017. 'Pola Asuh Dengan Kejadian Stunting Pada Balita Di Kabupaten Polewali Mandar'. Jurnal Kesehatan Manarang 2(1):21. doi: 10.33490/jkm.v2i1.9.

Yustianingrum, Lury Novita, \& Merryana Adriani. 2017. 'Perbedaan Status Gizi Dan Penyakit Infeksi Pada Anak Baduta Yang Diberi ASI Eksklusif Dan Non ASI Eksklusif'. Amerta Nutrition 1(4):415. doi: 10.20473/amnt.v1i4.7128.

10.36085/avicenna.v14i02.374. 